\title{
PERMAINAN DUET PIANO EMPAT TANGAN \\ SEBAGAI UPAYA PENINGKATAN KEMAMPUAN MAHASISWA PADA PEMBELAJARAN PRAKTEK INSTRUMEN MAYOR II PIANO DI JURUSAN PENDIDIKAN SENI MUSIK
}

\author{
Francisca Xaveria Diah K. \\ Jurusan Pendidikan Seni Musik, FBS, Universitas Negeri Yogyakarta \\ E-mail: franxa22_2@yahoo.co.id
}

\begin{abstract}
ABSTRAK
Penelitian ini bertujuan untuk mendiskripsikan proses pembelajaran Praktek Instrumen Mayor II Piano melalui permainan duet piano empat tangan sebagai upaya peningkatan kemampuan mahasiswa. Penelitian ini menggunakan metode penelitian tindakan. Subyek penelitian adalah mahaisswa Jurusan Pendidikan Seni Musik Semester II yang mengambil matakuliah Praktek Instrumen Mayor II Piano Kelas B sejumlah 10 orang. Teknik pengumpulan data berupa observasi, wawancara, dokumentasi visual dan angket. Prosedur penelitian menggunakan dua siklus dengan masing-masing siklus terdiri atas empat pertemuan dan terdiri atas perencanaan, pelaksanaan, pengamatan dan refleksi. Hasil penelitian menunjukan bahwa permainan duet piano empat tangan dapat meningkatkan kemampuan mahasiswa pada pembelajaran Praktek Instrumen Mayor 2 Piano di Jurusan Pendidikan Seni Musik. Peningkatan ini ditunjukkan dengan hasil perolehan nilai masing-masing komponen bagi pasangan duet berada pada kategori baik dan tinggi dengan rentang nilai 76 - 90 di setiap akhir siklus terutama diakhir siklus II. Pembelajaran menggunakan permainan duet piano empat tangan dapat dikategorikan berhasil. Dalam hal ini sesuai dengan kriteria keberhasilan tindakan yang telah ditentukan, dan hasilnya adalah (a) mahasiswa mampu menggunakan tubuhnya dan mengatur posisi tubuh atau ruang gerak serta menempatkan partitur secara baik, (b) mahasiswa mampu memainkan bagian primo atau secondo dengan baik dan lancar dalam membaca partitur, (c) mahasiswa mampu memainkan sesuai irama dan terlihat jelas alur melodinya, (d) mahasiswa mampu menjaga keseimbangan tempo dan harmonisasi dengan baik, serta menghasilkan warna suara / tone colour yang bulat dan indah didengar, serta (e) mahasiswa mampu menggunaan komunikasi verbalnonverbal dan bekerja sama dengan baik dalam praktek bermain duet piano empat tangan.
\end{abstract}

Kata kunci: permainan duet piano empat tangan, peningkatan kemampuan, pembelajaran. 


\title{
The Practice of Piano Four Hands as the Effort to increase Students' Ability in the Learning of Major Instrument II Piano Practice Course in the Department of Music Education
}

\begin{abstract}
This study aimed to describe the learning process of piano practice course of Major Instrument II with piano four hands as an effort to improve students' ability. Action research method was applied in this research. The subjects of this research were 10 second-semester first-year students of the Department of Music Education who took the piano practice course of Major Instrument II in Class B. The data collection techniques is conducted through observation, interviews, test practice, visual documentation and questionnaires. The research procedures use two cycles, each of which consists of four meetings including planning, implementation, observation and reflection. The results showed that piano four hands can improve students' ability in learning the Practice Course of Piano Major II in the Department of Music Education. This improvement is shown by the results of the acquisition value of each component for a duet partner, which are in the category of good and high, with a range of grades between 76-90 at the end of each cycle, especially at the end of the second cycle. The learning of piano four hands could be considered successful. In this case it is in accordance with the success criteria specified actions, and the results are (a) the students are able to use their body and adjust the position of the body or space as well as putting the score well, (b) the students were able to play a part primo or secondo well and smoothly in reading scores, (c) the students were able to play the beat by clearly showing the groove melody, (d) the students were able to maintain balance and harmony with a good tempo, and to produce the timbre / tone color which is thick and beautiful to hear, and (e) the students were able to use any verbal-nonverbal communication and work together well in practicing piano four hands.
\end{abstract}

Keywords: playing piano four hands, capacity building, learning.

\section{PENDAHULUAN}

Jurusan Pendidikan Seni Musik memiliki dua program unggulan salah satunya Praktek Instrumen Mayor (PIM), dengan instrumen atau alat musik dipilih sesuai keinginan setiap mahasiswa. PIM 2 Piano sebagai pilihan dilaksanakan pada semester genap, dengan prasyarat lulus (wajib lulus) pada perkuliahan PIM 1 Piano yang diselenggarakan di semester ganjil. 
Saat mengikuti perkuliahan PIM sebelumnya, mahasiswa baru memiliki kemampuan membaca partitur piano secara benar. Kemampuan tersebut diantaranya adalah menempatkan nada-nada notasi balok dalam dua paranada yang menggunakan kunci $\mathrm{G}$ dan $\mathrm{F}$ di atas tuts piano, memainkan notasi sesuai dengan nilai dan ketukannya, serta mampu bermain mengikuti tempo yang mendekati benar seperti yang tercantum pada partitur piano. Dalam hal ini, materi yang didapatkan pun hanya seputar pada pengolahan kemampuan secara teknik berupa materi permainan tangganada dan trinada, etude serta lagu sederhana yang mendukung kemampuan membaca partitur.

Standar kompetensi yang ingin dicapai pada perkuliahan PIM 2 Piano ini adalah mahasiswa memiliki kemampuan untuk menginterpretasikan lagu. Kemampuan interpretasi ini meliputi permainan dengan irama dan alur melodi yang dipengaruhi oleh keseimbangan tempo, serta harmonisasi yang dipengaruhi oleh pada hasil warna suara (tone colour) dan dinamik. Oleh karena itu, pada setiap materi kuliah yang diberikan, diharapkan mahasiswa dapat menginterpretasikan secara baik menurut kemampuan bermain piano yang telah diperoleh sebelumnya.

Permainan solo piano yang menjadi andalan dalam pelaksanaan kegiatan perkuliahan PIM 2 Piano, pada akhirnya akan menghasilkan mahasiswa yang individualis. Hal ini dirasakan tidak cukup baik untuk perkembangan musikalitas mahasiswa. Berdasarkan hasil pengamatan selama ini, beberapa mahasiswa merasa sadar akan situasi yang mereka hadapi. Oleh karena itu, saat materi perkuliahan diberikan dalam bentuk etude dan lagu dengan judul yang sama, mereka akan bermain secara bersama, berdua pada satu piano atau lebih dari dua orang pada piano yang lainnya. Saat itu mereka juga saling mengoreksi kekurangan dan kesalahan yang dibuat. Secara tidak langsung, kegiatan ini sebenarnya dapat meningkatkan kemampuan bermain piano mereka. Hanya saja karena mahasiswa belum mengenal istilah duet, trio, kwartet dan sebagainya dalam bermain piano, maka ketika mereka bermain berdua atau lebih, partiturnya sama tetapi dimainkan dalam oktaf yang berbeda.

Partitur duet piano terdiri atas primo dan secondo. Bagian primo dimainkan oleh seseorang yang berada di sisi sebelah kanan, dengan membaca paranada dalam kunci $\mathrm{G}$ untuk kedua tangan, sedangkan bagian secondo dimainkan oleh seseorang 
yang berada di posisi sebelah kiri, dengan membaca paranada dalam kunci $\mathrm{F}$ untuk kedua tangan. Bagian primo lebih menekankan pada permainan melodi utama lagu, sedangkan bagian secondo lebih menitikberatkan pada permainan dalam bentuk iringan lagu. Melihat situasi seperti ini, maka diadakan penelitian tentang permainan duet piano empat tangan. Hal ini dilakukan sebagai upaya dalam meningkatkan kemampuan mahasiswa dalam bermain piano dan membantu perkembangan musikalitas yang ada pada setiap individu, melalui pembelajaran PIM 2 Piano.

\section{TINJAUAN PUSTAKA}

\section{Pembelajaran dan Metodenya}

Pembelajaran merupakan suatu upaya yang dilakukan oleh pendidik untuk menyampaikan ilmu pengetahuan, mengorganisasi dan menciptakan suasana belajar dengan menggunakan berbagai metode, sehingga siswa dapat melakukan kegiatan belajar secara efektif dan mendapatkan hasil yang optimal (Sugihartono, dkk. 2007:81). Menurut Sanjaya (2009:63) bahwa tujuan pembelajaran merupakan pengikat segala aktivitas guru dan siswa, maka dari itu merumuskan tujuan pembelajaran merupakan langkah penting pertama yang harus dilakukan dalam merancang sebuah program pembelajaran. Untuk mencapai tujuan pembelajaran terutama pembelajaran bersifat praktek, maka dibutuhkan metode pembelajaran yaitu metode ceramah, metode tanya jawab, metode demonstrasi, serta metode latihan atau drill (Sugihartono, dkk. 2007, 82 - 85). Materi atau bahan ajar adalah segala sesuatu yang menjadi isi kurikulum yang harus dikuasai peserta didik sesuai dengan standar kompetensi dan dibuat sesuai dengan tingkat kebutuhan peserta didik (Sanjaya, 2009:141).

\section{Kemampuan bermain piano}

Semiawan (1984:1) menyatakan bahwa kemampuan merupakan suatu daya untuk melakukan tindakan sebagai hasil dari pembawaan dan latihan. Menurut Winkel (1986:26) kemampuan belajar merupakan kemampuan untuk berhasil dalam studi di jenjang pendidikan tertentu. Kemampuan secara umum pun kemudian diartikan sebagai prestasi komparatif individu dalam berbagai tugas, meliputi 
kapasitas untuk memahami tugas dan untuk menemukan strategi pemecahan masalah yang sesuai (Sugihartono, 2007 :40-41).

Piano sebagai salah satu instrumen musik yang dipilih oleh mahasiswa Jurusan Pendidikan Seni Musik memiiki metode sendiri untuk mempelajarinya. Dr. Haruko Kataoka, seorang guru besar piano pada pengajaran piano sistem Suzuki, dalam sebuah seminar menjelaskan bahwa metode utama bermain piano yang baik adalah dengan menggunakan seluruh tubuh (Wahyuni, 2007 : 13). Yang dimaksud dengan seluruh tubuh adalah bagaimana seseorang dapat mengatur keseimbangan tubuh sehingga gerakan lengan dan jari-jari saat menekan tuts piano selama dikendalikan oleh otak dengan baik, maka akan menghasilkan warna suara (tone colour) yang baik pula atau enak untuk didengar serta dinikmati.

Selain itu, istilah metode klasik yang digunakan pada pembelajaran instrumen musik, termasuk di dalamnya adalah piano, diantaranya adalah : (1) latihan penempatan jari dengan benar; (2) sikap dan posisi badan saat bermain; (3) drill (latihan padat berulang kali) atas motif lagu; (4) tangga nada dalam jangkauan oktaf tertentu; (5) memainkan etude atau lembar (pieces) latihan teknik; (6) memainkan urutan buku menurut kurikulum; dan (7) memainkan komposisi musik (pieces) menurut pilihan guru sesuai dengan kemampuan siswa (Banoe, 2013:63).

Dalam bermain piano dibutuhkan beberapa kemampuan dasar yaitu (1) memahami sikap atau posisi saat bermain piano; (2) membaca partitur yang meliputi penempatan nada-nada notasi pada tuts piano, pola jari atau fingering, nilai nada dan ketukan yang berpengaruh pada ritmis dan irama; (3) memorizing; dan (4) interpretasi. Dengan demikian kemampuan bermain piano dapat diartikan sebagai kesanggupan dalam berlatih piano untuk meningkatkan kemampuan dasar sebagai suatu prestasi.

\section{Permainan duet piano empat tangan}

Permainan duet piano dimulai pada tahun 1765 di London oleh Wolfgang Amadeuz Mozart dan saudara perempuannya Maria Anna menggunakan dua harpsicord. Duet piano Mozart menjadi inspirasi bagi komponis dan pianis lainnya, sehingga berkembang cukup pesat di Eropa dan Amerika. Duet piano empat tangan 
juga semakin populer setelah terjadi Revolusi Perancis para kaum aristrokat mengalami kebangkrutan. Mereka biasa menikmati musik orkes, namun sejak peristiwa tersebut mereka tetap ingin mendengarkan musik meski melalui permainan duet piano empat tangan. Muzio Clementi juga mengadakan resital duet piano empat tangan. Carl Czerny, Beethoven dan Franz Schubert, Felix Mendelssohn, Clara Schuman, Antonin Dvorak, Johannes Brahms dan Franz Liszt adalah tokoh komponis sekaligus pianis duet piano empat tangan (Megawati, 2014 : 14).

Sonata for Due adalah karya komposisi Charles Burney yang khusus dibuat untuk permainan duet piano empat tangan. Karya ini dipublikasikan pertama kali sekitar tahun 1777 di London. Burney mengatakan bahwa permainan duet lebih menantang dan membutuhkan latihan ekstra dari pada permainan solo atau dua piano. Tantangan itu adalah bagaimana keduanya tetap dapat memainkan lagu secara tepat sedangkan pada saat yang bersamaan harus tetap berkonsentrasi bermain lebih jauh dengan fleksibilitas dan tetap menjaga keseimbangan tangan-tangan tersebut (Wahyurini, 2009:40)

Sama halnya dengan permainan solo piano, permainan duet empat tangan membutuhkan teknik dan kemampuan pendengaran yang baik. Sikap kerja sama dalam permainan duet dapat mengembangkan pertumbuhan musikalitas seseorang (Last, 1989:110). Thomas Beecham dalam Jelia Megawati Heru (2014:13-14) mengungkapkan beberapa hal yang perlu diperhatikan dalam permainan piano duet empat tangan yaitu : (1) Patner atau teman, (2) Posisi bermain, (3) Karya Repertoar, (4) Membaca partitur, (5) Primo dan Secondo, (6) Penjarian dan Teknik Pedal, dan (7) Kesatuan dan keseimbangan.

\section{METODE PENELITIAN}

Penelitian ini menggunakan metode pendekatan penelitian tindakan. Pemilihan pendekatan ini dilakukan karena penelitian bersifat praktis dan langsung relevan untuk situasi aktual. Selain itu penelitian tindakan bersifat fleksibel dan adaptif dengan membolehkan perubahan guna mengembangkan keterampilan baru atau cara pendekatan baru untuk memecahkan masalah (Suryabrata, 2013:94). Dalam penelitian tindakan, peneliti terjun langsung dan melibatkan diri selama proses 
pembelajaran berlangsung dan diikuti secara terus - menerus. Penelitian tindakan dilakukan dengan tujuan memperbaiki mutu praktek pembelajaran di dalam kelas (Kunandar, 2008:45).

Peneliti melakukan tindakan berupa ceramah diawal pertemuan untuk menyampaikan tujuan dan materi pembelajaran, demontrasi bersama seorang mahasiswa dalam memberi contoh praktek bermain duet dan tanya jawab dengan mahasiswa membahas bagaimana mereka dapat memainkan karya lagu duet piano. Selama mahasiswa melakukan latihan atau diberi tindakan dengan drill, peneliti mendampingi di samping mahasiswa untuk mengecek permainan duet piano mereka sekaligus memberikan penjelasan apabila dalam permainan tersebut terdapat kekurangan atau kesalahan.

Penelitian ini dilaksanakan di Jurusan Pendidikan Seni Musik FBS UNY untuk mata kuliah Praktek Instrumen Mayor II Piano. Penelitian berlangsung selama masa perkuliahan semester genap tahun ajaran 2014/2015 yaitu mulai bulan Februari sampai dengan bulan Juni tahun 2015. Subyek penelitian adalah mahasiswa Jurusan Pendidikan Seni Musik Semester II yang mengambil matakuliah Praktek Instrumen Mayor II Piano kelas B sejumlah 10 orang. Dipilihnya subyek ini dengan pertimbangan hasil pengamatan dan pembelajaran pada mata kuliah Piano semester sebelumnya.

Pengumpulan data dilakukan dengan observasi, tes praktik, wawancara, dokumentasi visual dan angket. Prosedur penelitian mengikuti model yang dikemukakan oleh Kemmis dan Taggart dilaksanakan dalam dua siklus.

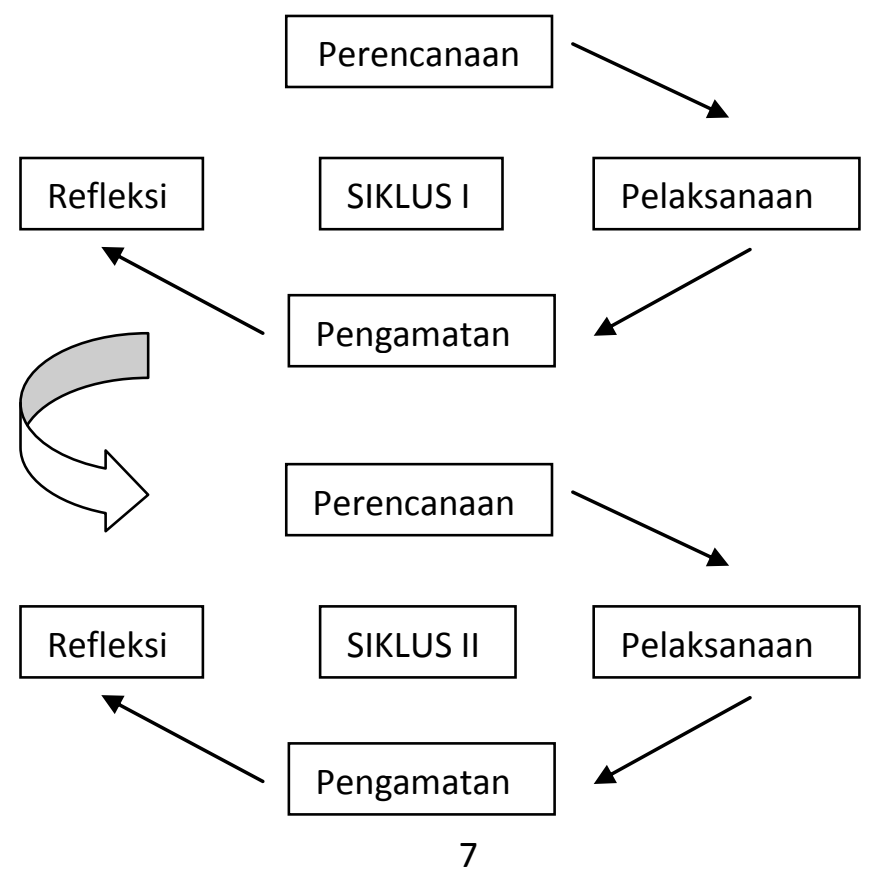




\section{Gambar 1. Langkah Pelaksanaan Tindakan}

(Sumber : Arikunto, $2014: 16$ )

Siklus Pertama yakni (1) perencanaan terdiri atas menetapkan waktu pelaksanaan penelitian bersama kolaborator yaitu Dosen Piano Jurusan Pendidikan Seni Musik, mempersiapkan kelas, piano dan mahasiswa yang akan diteliti, menentukan materi duet dan menyiapkan instrumen observasi dan penilaian. (2) Pelaksanaan tindakan dilakukan dengan menyampaikan tujuan materi, menjelaskan materi permainan duet piano empat tangan, mendemonstasikan materi permainan duet piano empat tangan, melatih mahasiswa dalam permainan duet piano empat tangan, mengamati aktivitas proses latihan mahasiswa di dalam kelas, mahasiswa menampilkan hasil latihan bermain duet piano empat tangan dan memberikan penilaian terhadap proses dan hasil permainan duet piano empat tangan mahasiswa. (3) Pengamatan meliputi situasi kegiatan perkuliahan, keaktifan dan partisipasi mahasiswa, dan kemampuan mahasiswa dalam bekerja sama dan menyelesaikan tugas. (4) Refleksinya adalah mahasiswa dapat memahami dan mengerti saat dijelaskan mengenai tujuan, materi dan demontrasi, sehingga selama aktivitas pembelajaran mahasiswa dapat berlatih dan menampilkan hasil latihan dan bekerja sama dalam permainan duet piano empat tangan sebagai bentuk penyelesaian tugas.

Siklus kedua terdiri atas (1) Perencanaan, membuat rencana pembelajaran berdasarkan hasil refleksi siklus pertama. (2) Pelaksanaan, melaksanakan pembelajaran permainan duet piano empat tangan berdasar rencana pembelajaran hasil refleksi pada siklus pertama. (3) Pengamatan, melakukan pengamatan terhadap aktivitas pembelajaran PIM 2 Piano. (4) Refleksi, melakukan refleksi terhadap pelaksanaan siklus kedua dan menganalisis serta membuat kesimpulan atas proses pembelajaran permainan duet piano empat tangan sebagai upaya peningkatan kemampuan mahasiswa dalam pembelajaran PIM 2 Piano.

Penelitian tindakan kelas ini berhasil apabila mengalami peningkatan dengan kriteria Baik / Tinggi (nilai 76 - 90) dan memenuhi komponen yaitu bahwa mahasiswa mampu menggunakan tubuhnya dan mengatur posisi tubuh atau ruang gerak serta menempatkan partitur secara baik, mampu memainkan bagian primo 
atau secondo dengan baik dan lancar dalam membaca partitur, mampu memainkan sesuai irama dan terlihat jelas alur melodinya, mampu menjaga keseimbangan tempo dan harmonisasi dengan baik, serta menghasilkan warna suara / tone colour yang bulat dan indah didengar,dan mahasiswa mampu menggunaan komunikasi verbalnonverbal dan bekerja sama dengan baik dalam praktek bermain duet piano empat tangan.

Teknik analisis data dilakukan dengan analisis kualitatif dengan mendeskripsikan hasil belajar pada pembelajaran piano menggunakan permainan duet piano empat tangan dengan kategori tinggi, sedang dan rendah, aktivitas mahasiswa dalam proses belajar mengajar dengan kategori baik, cukup dan sedang, serta permainan duet piano empat tangan sebagai upaya peningkatan kemampuan mahasiswa dengan kategori berhasil, kurang berhasil dan tidak berhasil.

\section{HASIL DAN PEMBAHASAN}

Pada tahap pra-siklus, proses belajar mengajar berlangsung seperti biasanya dilaksanakan dalam dua pertemuan. Pada pertemuan pertama, saat itu tidak ada hal yang direncanakan secara khusus untuk melakukan proses tindakan. Mahasiswa menerima materi piano yang dimainkan secara tunggal. Setelah itu mahasiswa diberikan materi duet piano empat tangan berupa etude dan lagu pendek. Masingmasing mahasiswa memiliki pasangan yang telah ditunjuk oleh dosen yang sekaligus sebagai peneliti. Saat itu dosen hanya mengarahkan bahwa mereka akan main berdua dengan satu piano. Dalam waktu kurang lebih 100 menit di pertemuan pertama, mahasiswa hanya berlatih sendiri tanpa ada arahan. Di sini peneliti melakukan pengamatan terhadap aktivitas pembelajaran.

Pada pertemuan kedua, mahasiswa diminta memainkan materi yang telah diberikan. Masing-masing pasangan duet terlihat mengalami beberapa kendala terutama untuk mengharmonisasikan keempat tangan dan menjaga keseimbangan tempo. Hanya saja kondisi yang terlihat mahasiswa tersebut tidak begitu lancar untuk membaca partitur, sehingga setiap ada kesalahan dari salah satu pasangan, materi lagu kemudian diulang-ulang selalu ditempat yang sama. Semua pasangan duet tidak dapat menyelesaikan lagu dengan baik. Melihat keadaan ini, maka mulai diadakan perencanaan guna melakukan tahap siklus I. 
Tabel 1. Hasil Penilaian Praktek Duet pada Pra-siklus

\begin{tabular}{|c|l|c|c|c|c|c|c|c|}
\hline No & \multicolumn{1}{|c|}{ Komponen } & $\begin{array}{c}\text { Pasangan } \\
1\end{array}$ & $\begin{array}{c}\text { Pasangan } \\
2\end{array}$ & $\begin{array}{c}\text { Pasangan } \\
3\end{array}$ & $\begin{array}{c}\text { Pasangan } \\
4\end{array}$ & $\begin{array}{c}\text { Pasangan } \\
5\end{array}$ & Jumlah & $\begin{array}{c}\text { Rata- } \\
\text { rata }\end{array}$ \\
\hline 1 & $\begin{array}{l}\text { Posisi duduk / ruang gerak dan } \\
\text { penempatan partitur }\end{array}$ & 60 & 75 & 75 & 78 & 67 & 355 & $\mathbf{7 1}$ \\
\hline 2 & Peran Primo & 71 & 63 & 70 & 75 & 60 & 339 & $\mathbf{6 7 , 8}$ \\
\hline 3 & Peran Secondo & 73 & 61 & 68 & 70 & 60 & 332 & $\mathbf{6 6 , 4}$ \\
\hline 4 & Irama dan alur melodi & 70 & 61 & 58 & 75 & 50 & 314 & $\mathbf{6 2 , 8}$ \\
\hline 5 & Harmonisasi & 70 & 61 & 58 & 75 & 50 & 314 & $\mathbf{6 2 , 8}$ \\
\hline 6 & Kelancaran membaca partitur & 71 & 60 & 55 & 72 & 50 & 308 & $\mathbf{6 1 , 6}$ \\
\hline 7 & Tone atau warna suara & 71 & 60 & 55 & 72 & 50 & 308 & $\mathbf{6 1 , 6}$ \\
\hline 8 & Keseimbangan tempo & 71 & 60 & 55 & 73 & 50 & 309 & $\mathbf{6 1 , 8}$ \\
\hline 9 & Komunikasi verbal - nonverbal & 80 & 80 & 80 & 80 & 80 & 400 & $\mathbf{8 0}$ \\
\hline 10 & Kerjasama & 80 & 76 & 76 & 76 & $\mathbf{7 5}$ & 383 & $\mathbf{7 6 , 6}$ \\
\hline & Jumlah Nilai & 717 & 657 & 650 & $\mathbf{7 4 6}$ & 592 & & \\
\hline & Rata-rata & $\mathbf{7 1 , 7}$ & $\mathbf{6 5 , 7}$ & $\mathbf{6 5}$ & $\mathbf{7 4 , 6}$ & $\mathbf{5 9 , 2}$ & & \\
\hline
\end{tabular}

Tahap siklus I ( empat pertemuan) dilaksanakan melalui empat tahapan yaitu :

1. Perencanaan terdiri atas (a) Menetapkan bahwa waktu pelaksanaan penelitian untuk pertemuan pertama dimulai pada minggu ketiga sesuai jadwal perkuliahan semester genap yang direncanakan selama 14 minggu. (b) Mempersiapkan kelas menggunakan ruang di C.29.102, piano terdiri atas 20 piano elektrik dan 2 piano akustik, dengan jumlah mahasiswa yang diteliti adalah 10 orang terdiri atas 6 orang mahasiswa laki-laki dan 4 orang mahasiswa perempuan. (c) Menentukan materi duet piano empat tangan, berdasarkan kemampuan masing-masing pasangan. Setiap pasangan ditunjuk dengan pertimbangan bahwa mereka memiliki kemampuan rata-rata sama dalam bermain piano. Materi terdiri atas 1 lagu dengan variasi, 3 lagu pendek satu bagian dan 1 etude. (d) Menyiapkan instrumen observasi dan penilaian.

2. Pelaksanaan tindakan dengan (a) menyampaikan tujuan materi yang diberikan hanya pada pertemuan pertama. Selanjutnya pertemuan kedua dan ketiga tidak lagi diberikan penjelasan. Tujuan dari diadakannya praktek permainan piano dengan duet empat tangan adalah meningkatkan kemampuan bermain piano baik secara individu maupun berpasangan. (b) Menjelaskan materi permainan duet piano empat tangan Mahasiswa duduk berpasangan dan mengamati partitur piano yang diberikan. Saat itu mereka diminta pula untuk menentukan siapa yang bermain bagian primo dan siapa yang bermain bagian secondo, setelah dijelaskan 
masing-masing pengertian primo dan secondo. Selanjutnya mereka mengamati masing-masing bagiannya, melihat nilai nada, pola penjarian, pola ritmis, birama yang digunakan dan urutan birama yang harus dimainkan. (c) Mendemonstasikan materi permainan duet piano empat tangan. Dosen bersama dengan salah satu mahasiswa memainkan materi yang diberikan. Mahasiswa memainkan bagian yang telah dipilihnya dan dosen memainkan bagian pasangannya. Saat itu pula sekaligus dijelaskan bagaimana posisi atau sikap duduk saat bermain duet dan penempatan partitur di piano sehingga bisa terbaca oleh kedua pasangan. Disamping itu dosen juga memberi contoh bagaimana melakukan komunikasi verbal dan non-verbal dengan pasangan, sehingga terjadi keseimbangan dan kerjasama yang baik dengan pasangan. Selanjutnya dosen meminta pasangan dari mahasiswa tersebut untuk memainkan materi lagunya. (d) Melatih mahasiswa dalam permainan duet piano empat tangan. Setelah mahasiswa cukup jelas dengan tugasnya, selanjutnya mereka pada pertemuan kedua dan ketiga berlatih dengan pasangan masing-masing dan dosen serta kolaborator akan menanggapi apabila mereka menemui permasalahan. (e) Mengamati aktivitas proses latihan mahasiswa di dalam kelas. Selama proses latihan di dalam kelas, pasangan satu dengan lainnya juga ikut saling mengamati. Hal ini dikarenakan bermain piano duet tidak menggunakan earphone meskipun menggunakan piano elektrik. Untuk menghasilkan warna suara yang diinginkan, pasangan duet bermain menggunakan piano akustik. Setiap ada pasangan yang bermain dengan piano akustik, pasangan lain mengamati dan mendengarkan permainan pianonya. (f) Mahasiswa menampilkan hasil latihan bermain duet piano empat tangan. Target pertemuan keempat yaitu akhir dari tahap siklus I, masing-masing pasangan duet menampilkan hasil latihannya. Dosen bersama kolaborator memberikan penilaian terhadap proses dan hasil permainan duet piano empat tangan mahasiswa.

3. Pengamatan pada aktivitas perkuliahan PIM 2 Piano dengan materi duet empat tangan berjalan lancar dan baik. Setiap individu memiliki toleransi yang tinggi saat salah satu pasangan bermain menggunakan piano akustik, sehingga mereka yang menggunakan piano elektrik tidak ikut membunyikan piano yang tentu dapat merusak konsentrasi pasangan lainnya. Untuk dapat memainkan bagiannya secara lebih baik, mahasiswa kemudian dengan kesadarannya masing-masing 
menggunakan piano elektrik dan earphone duduk sendiri-sendiri. Setelah mereka merasa cukup yakin untuk digabungkan, mereka akan memainkannya menggunakan piano akustik. Kadangkala ada mahasiswa yang secara tidak sengaja lupa menancapkan kabel earphonenya dan berbicara cukup keras, sehingga pasangan yang sedang praktek sempat terganggu konsentrasinya.

4. Refleksi yang diperoleh setelah tahapan siklus pertama dilaksanakan yakni adanya hal-hal yang menjadi kekurangan selama pelaksanaan. Hal tersebut adalah (a) Posisi duduk rata-rata belum baik sehingga diantara mereka ruang gerak untuk jari dan tangan menjadi tidak leluasa. Mereka menggunakan kursi yang kecil untuk diduduki oleh dua orang sehingga ruang geraknya terbatas. Hal ini juga mempengaruhi posisi mereka dalam menempatkan partitur. Partitur piano tidak diletakkan di standpart tetapi di bagian lain di piano yang penting partitur dapat terlihat jelas. Selain itu ada pasangan yang partiturnya ganda yakni dua primo dan dua secondo diletakkan berdampingan, karena mereka merasa belum yakin dengan kemampuan baca mereka. (b) Ketidakyakinan dengan kemampuan membaca partitur sangat mempengaruhi peran primo dan secondo, sehingga irama dan alur melodi menjadi tidak jelas. Harmonisasi, warna suara dan keseimbangan tempo menjadi kurang terbentuk oleh karena apabila ada salah satu dari pasangan tiba-tiba berhenti karena melakukan kesalahan waktu membaca partitur, secara otomatis pasangannya ikut berhenti. Lagu kemudian diulang kembali, dan tak jarang pula salah satu lupa posisi birama mana yang akan dimainkan kembali, disini sering terjadi diskusi cukup lama. Akhirnya kerjasama belum dapat tercapai, karena tak jarang salah satu pasangan bermain sampai selesai, namun pasangannya berhenti ditengah sampai lagu selesai. 


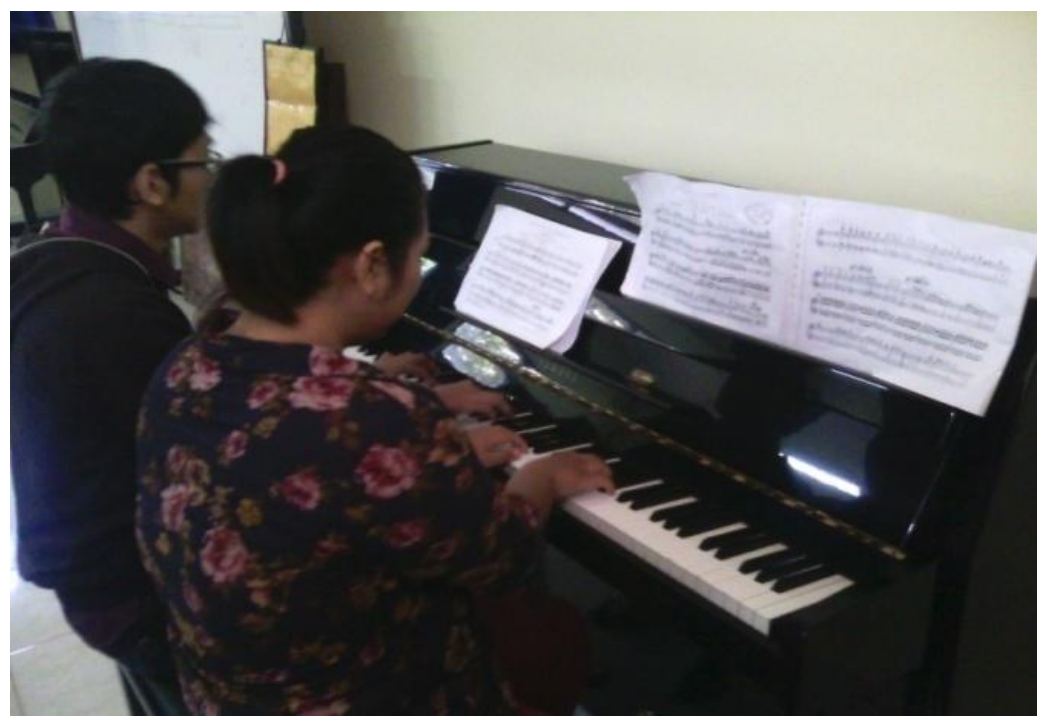

Gambar 2.

Penempatan partitur piano yang kurang baik (dok : Diah, Maret 2015)

Tabel 2. Hasil Penilaian Praktek Duet pada Siklus 1

\begin{tabular}{|c|l|c|c|c|c|c|c|c|}
\hline No & \multicolumn{1}{|c|}{ Komponen } & $\begin{array}{c}\text { Pasangan } \\
1\end{array}$ & $\begin{array}{c}\text { Pasangan } \\
2\end{array}$ & $\begin{array}{c}\text { Pasangan } \\
3\end{array}$ & $\begin{array}{c}\text { Pasangan } \\
4\end{array}$ & $\begin{array}{c}\text { Pasangan } \\
5\end{array}$ & Jumlah & $\begin{array}{c}\text { Rata- } \\
\text { rata }\end{array}$ \\
\hline 1 & $\begin{array}{l}\text { Posisi duduk / ruang gerak dan } \\
\text { penempatan partitur }\end{array}$ & 62 & 80 & 80 & 81 & 70 & 373 & $\mathbf{7 4 , 6}$ \\
\hline 2 & Peran Primo & 74 & 75 & 71 & 80 & 83 & 383 & $\mathbf{7 6 , 6}$ \\
\hline 3 & Peran Secondo & 80 & 70 & 71 & 80 & 65 & 366 & $\mathbf{7 3 , 2}$ \\
\hline 4 & Irama dan alur melodi & 80 & 70 & 63 & 80 & 61 & 354 & $\mathbf{7 0 , 8}$ \\
\hline 5 & Harmonisasi & 80 & 70 & 63 & 80 & 61 & 354 & $\mathbf{7 0 , 8}$ \\
\hline 6 & Kelancaran membaca partitur & 81 & 68 & 62 & 81 & 58 & 350 & $\mathbf{7 0}$ \\
\hline 7 & Tone atau warna suara & 81 & 68 & 62 & 81 & 58 & 350 & $\mathbf{7 0}$ \\
\hline 8 & Keseimbangan tempo & 78 & 65 & 64 & 85 & 59 & 351 & $\mathbf{7 0 , 2}$ \\
\hline 9 & Komunikasi verbal - nonverbal & 85 & 85 & 85 & 85 & 85 & 425 & $\mathbf{8 5}$ \\
\hline 10 & Kerjasama & 85 & 80 & 80 & 81 & 76 & 402 & $\mathbf{8 0 , 4}$ \\
\hline & Jumlah Nilai & $\mathbf{7 8 6}$ & 731 & 701 & 814 & 676 & & \\
\hline & Rata-rata & $\mathbf{7 8 , 6}$ & $\mathbf{7 3 , 1}$ & $\mathbf{7 0 , 1}$ & $\mathbf{8 1 , 4}$ & $\mathbf{6 7 , 6}$ & & \\
\hline
\end{tabular}

Tahap Siklus II (empat pertemuan) dilakukan sebagai hasil refleksi siklus pertama, sehingga untuk dapat lebih meningkatkan kemampuan bermain piano mahasiswa siklus ini juga melalui empat tahapan yakni :

1. Perencanaan dengan (a) Menetapkan kembali bahwa waktu pelaksanaan penelitian untuk pertemuan pertama dimulai pada minggu ketujuh pada masa perkuliahan semester genap. (b) Mempersiapkan kelas menggunakan ruang di 
C.29.102, piano terdiri atas 20 piano elektrik dan 2 piano akustik, dengan jumlah mahasiswa yang diteliti adalah 10 orang terdiri atas 6 orang mahasiswa laki-laki dan 4 orang mahasiswa perempuan. (c) Menentukan materi duet piano empat tangan, berdasarkan kemampuan masing-masing pasangan, dengan melanjutkan materi yang sebelumnya. Pasangan masih tetap seperti pada siklus pertama. Penambahan materi yang akan dinilai terdiri atas 1 lagu dengan variasi, 3 lagu pendek satu bagian dan 1 etude adalah penggunaan dinamik dan interpretasi. (d) Menyiapkan instrumen observasi dan penilaian.

2. Pelaksanaan tindakan dengan (a) Menyampaikan tujuan materi yang juga diberikan hanya pada pertemuan pertama terutama penambahan materi yang akan dinilai yaitu dinamika dan interpretasi. Selanjutnya pertemuan kedua, ketiga dan keempat tidak lagi diberikan penjelasan. Tujuan penambahan materi penilaian agar kemampuan bermain piano mahasiswa semakin meningkat baik secara individu maupun berpasangan. (b) Menjelaskan kembali materi permainan duet piano empat tangan. Mahasiswa duduk berpasangan dan mengamati partitur piano yang diberikan secara lebih rinci dibandingkan pada siklus I. Setelah menentukan kembali siapa yang akan bermain bagian primo dan siapa yang akan bermain bagian secondo, mengamati masing-masing bagiannya, melihat nilai nada, pola penjarian, pola ritmis, birama yang digunakan dan urutan birama yang harus dimainkan, dosen kemudian menjelaskan penggunaan dinamik seperti ada yang tertulis di partitur dan bagaimana menginterpretasikan lagu sehingga baik untuk di dengarkan dan dinikmati. (c) Mendemonstasikan materi permainan duet piano empat tangan. Dosen bersama dengan salah satu mahasiswa memainkan materi yang diberikan lengkap dengan contoh penggunaan dinamika dan interpretasi. Mahasiswa memainkan bagian yang telah dipilihnya dan dosen memainkan bagian pasangannya. Saat itu pula sekaligus dijelaskan kembali bagaimana posisi atau sikap duduk saat bermain duet dan penempatan partitur di piano sehingga bisa terbaca oleh kedua pasangan. Disamping itu dosen juga memberi contoh bagaimana melakukan komunikasi verbal dan non-verbal dengan pasangan, sehingga terjadi keseimbangan dan kerjasama yang baik dengan pasangan. Selanjutnya dosen meminta pasangan dari mahasiswa tersebut untuk memainkan materi lagunya. (d) Melatih mahasiswa dalam permainan duet piano empat 
tangan. Setelah mahasiswa cukup jelas dengan tugasnya, selanjutnya mereka pada pertemuan kedua, ketiga dan keempat berlatih dengan pasangan masing-masing dan dosen serta kolaborator akan menanggapi apabila mereka menemui permasalahan. (e) Mengamati aktivitas proses latihan mahasiswa di dalam kelas. Selama proses latihan di dalam kelas, pasangan satu dengan lainnya juga ikut saling mengamati. Hal ini dikarenakan bermain piano duet tidak menggunakan earphone meskipun menggunakan piano elektrik. Untuk menghasilkan warna suara yang diinginkan, pasangan duet bermain menggunakan piano akustik. Setiap ada pasangan yang bermain dengan piano akustik, pasangan lain mengamati dan mendengarkan permainan pianonya. Pada siklus kedua ini, mulai terlihat bagaimana masing-masing pasangan mulai lebih aktif dalam komunikasi verbal dan non-verbal, sehingga sudah dapat terlihat pula pola kerjasama yang baik diantara mereka. (f) Mahasiswa menampilkan hasil latihan bermain duet piano empat tangan.Target pertemuan kelima yaitu akhir dari tahap siklus II, masingmasing pasangan duet menampilkan hasil latihannya. Dosen bersama kolaborator memberikan penilaian terhadap proses dan hasil permainan duet piano empat tangan mahasiswa.

3. Pengamatan menunjukkan bahwa aktivitas perkuliahan PIM 2 Piano dengan materi duet empat tangan berjalan lancar dan baik. Setiap individu memiliki toleransi yang tinggi saat salah satu pasangan bermain menggunakan piano akustik, sehingga mereka yang menggunakan piano elektrik tidak ikut membunyikan piano yang tentu dapat merusak konsentrasi pasangan lainnya. Untuk dapat memainkan bagiannya secara lebih baik, mahasiswa kemudian dengan kesadarannya masing-masing menggunakan piano elektrik dan earphone duduk sendiri-sendiri. Setelah mereka merasa cukup yakin untuk digabungkan, mereka akan memainkannya menggunakan piano akustik. Proses kerjasama juga sudah mulai nampak. Hal ini terlihat dari penggunaan dinamik sebagai tambahan materi penilaian, sehingga warna suara yang dihasilkan menjadi lebih baik. Selain itu masing-masing individu memiliki penghayatan yang baik, maka interpretasi yang dihasilkan setiap pasangan menjadi baik.

4. Refleksi, setelah tahapan siklus kedua dilaksanakan, ada hal-hal yang menjadi kekurangan selama pelaksanaan sudah tidak tampak lagi. Posisi duduk rata-rata 
sudah baik sehingga diantara mereka ruang gerak untuk jari dan tangan menjadi lebih leluasa. Mereka menggunakan kursi yang lebih lebar untuk diduduki oleh dua orang, bahkan bisa dengan dua kursi sehingga ruang geraknya menjadi lebih bebas. Dalam menempatkan partitur juga lebih baik yaitu sesuai dengan perannya masing-masing. Hal yang sangat jelas terlihat adalah masing-masing individu sudah yakin bahwa kemampuan membaca partitur meningkat. Sudah tidak ada pasangan yang memainkan lagu yang tiba-tiba berhenti ditengah. Secara memori, mereka sudah sangat hafal dengan bagiannya dan alur melodi sudah lebih jelas. Harmonisasi dan keseimbangan tempo juga sudah tampak. Disinilah sikap kerjasama yang dilakukan berhasil dengan baik.

Tabel 3. Hasil Penilaian Praktek Duet pada Siklus 2

\begin{tabular}{|c|l|c|c|c|c|c|c|c|}
\hline No & \multicolumn{1}{|c|}{ Komponen } & $\begin{array}{c}\text { Pasangan } \\
1\end{array}$ & $\begin{array}{c}\text { Pasangan } \\
2\end{array}$ & $\begin{array}{c}\text { Pasangan } \\
3\end{array}$ & $\begin{array}{c}\text { Pasangan } \\
4\end{array}$ & $\begin{array}{c}\text { Pasangan } \\
5\end{array}$ & Jumlah & $\begin{array}{l}\text { Rata- } \\
\text { rata }\end{array}$ \\
\hline 1 & $\begin{array}{l}\text { Posisi duduk / ruang gerak } \\
\text { dan penempatan partitur }\end{array}$ & 65 & 81 & 81 & 85 & 76 & 388 & $\mathbf{7 7 , 6}$ \\
\hline 2 & Peran Primo & 84 & 80 & 78 & 85 & 76 & 403 & $\mathbf{8 0 , 6}$ \\
\hline 3 & Peran Secondo & 84 & 80 & 78 & 86 & 70 & 398 & $\mathbf{7 9 , 6}$ \\
\hline 4 & Irama dan alur melodi & 87 & 80 & 78 & 88 & 63 & 396 & $\mathbf{7 9 , 2}$ \\
\hline 5 & Harmonisasi & 87 & 80 & 78 & 88 & 63 & 396 & $\mathbf{7 9 , 2}$ \\
\hline 6 & $\begin{array}{l}\text { Kelancaran } \\
\text { partitur }\end{array}$ & 87 & 77 & 76 & 88 & 63 & 391 & $\mathbf{7 8 , 2}$ \\
\hline 7 & Tone atau warna suara & 87 & 77 & 76 & 88 & 63 & 391 & $\mathbf{7 8 , 2}$ \\
\hline 8 & Keseimbangan tempo & 85 & 76 & 77 & 90 & 65 & 393 & $\mathbf{7 8 , 6}$ \\
\hline 9 & $\begin{array}{l}\text { Komunikasi verbal } \\
\text { nonverbal }\end{array}$ & 90 & 90 & 90 & 90 & 90 & 450 & $\mathbf{9 0}$ \\
\hline 10 & Kerjasama & 90 & 85 & 83 & 90 & 77 & 425 & $\mathbf{8 5}$ \\
\hline & Jumlah Nilai & 846 & 806 & $\mathbf{7 9 5}$ & 878 & $\mathbf{7 0 6}$ & & $\mathbf{7 0 6}$ \\
\hline & Rata-rata & $\mathbf{8 4 , 6}$ & $\mathbf{8 0 , 6}$ & $\mathbf{7 9 , 5}$ & $\mathbf{8 7 , 8}$ & $\mathbf{7 0 , 6}$ & & \\
\hline
\end{tabular}

Setelah mengamati dan memberikan tindakan selama proses pembelajaran maka diperoleh nilai rata-rata dari 10 komponen dan dari 5 pasangan duet sebagai berikut : 


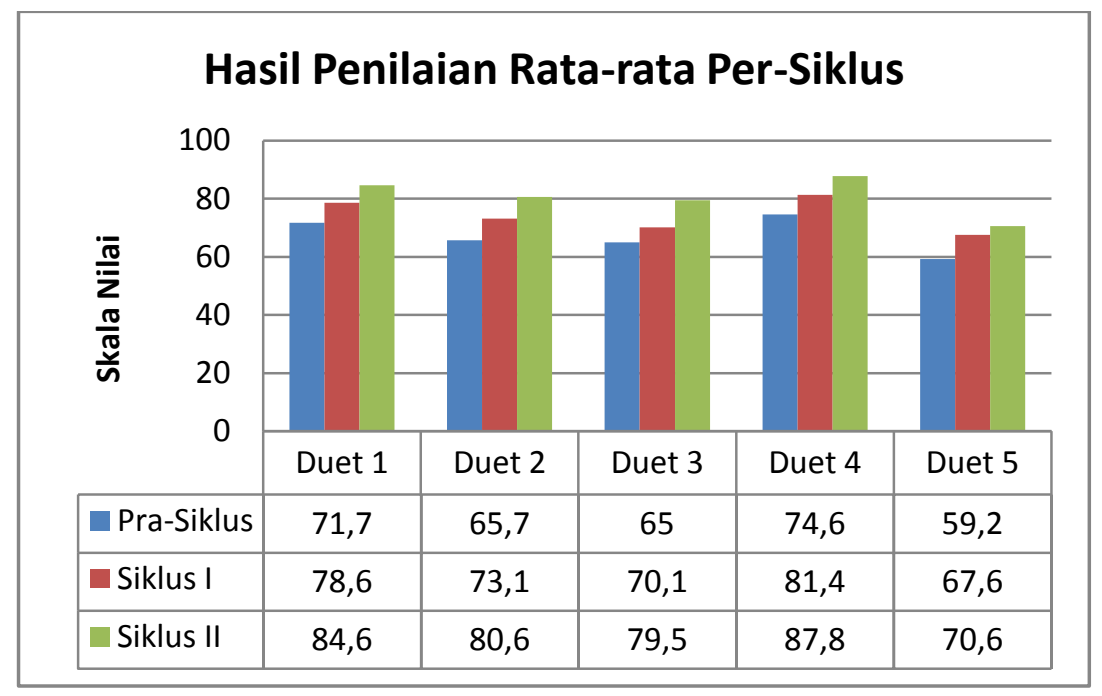

Gambar 2. Grafik hasil penilaian atas tindakan per-siklus

Pada grafik terlihat adanya peningkatan di setiap siklus, sehingga pembelajaran piano menggunakan permainan duet piano empat tangan berhasil baik. Berdasarkan hipotesis yang dikemukakan sebelumnya bahwa dengan permainan duet piano empat tangan dapat meningkatkan kemampuan mahasiswa pada pembelajaran Praktek Instrumen Mayor 2 Piano di Jurusan Pendidikan Seni Musik telah terbukti. Hal ini sesuai dengan kriteria keberhasilan tindakan yang ditentukan yakni memenuhi komponen sebagai berikut :

a. Mahasiswa mampu menggunakan tubuhnya dan mengatur posisi tubuh atau ruang gerak serta menempatkan partitur dengan rata-rata nilai meningkat dari pra-siklus nilainya 71 , siklus pertama nilainya 74,6 dan siklus kedua nilainya 77,6 .

b. Mahasiswa mampu memainkan bagian primo dengan rata-rata nilai meningkat dari pra-siklus nilainya 67,8, siklus pertama nilainya 76,4 dan siklus kedua nilainya 80,6 . Bagian secondo denga rata-rata nilai meningkat dari pra-siklus nilainya 66,4, siklus pertama nilainya 73,2 dan siklus kedua nilainya 79,6. Mahasiswa lancar dalam membaca partitur dengan rata-rata nilai meningkat dari pra-siklus nilainya 61,6 , siklus pertama nilainya 70 dan siklus kedua nilainya 78,2 .

c. Mahasiswa mampu memainkan sesuai irama dan terlihat jelas alur melodinya dengan rata-rata nilai meningkat dari pra-siklus nilainya 62,8 siklus pertama nilainya 70,8 dan siklus kedua nilainya 79,2. 
d. Mahasiswa mampu menjaga keseimbangan tempo dengan rata-rata nilai meningkat dari pra-siklus nilainya 61,8, siklus pertama nilainya 70,2 dan siklus kedua nilainya 78,6. Harmonisasi dengan rata-rata nilai meningkat dari prasiklus nilainya 62,8, siklus pertama nilainya 70,8 dan siklus kedua nilainya 79,2. Menghasilkan warna suara / tone colour yang bulat dan indah didengar dengan rata-rata nilai meningkat dari pra-siklus nilainya 61,6 , siklus pertama nilainya 70 dan siklus kedua nilainya 78,2.

e. Mahasiswa mampu menggunaan komunikasi verbal-nonverbal dengan rata-rata nilai meningkat dari pra-siklus nilainya 80 , siklus pertama nilainya 85 dan siklus kedua nilainya 90, dan bekerja sama dengan baik dalam praktek bermain duet piano empat tangan rata-rata nilai meningkat dari pra-siklus nilainya 76,6 , siklus pertama nilainya 80,4 dan siklus kedua nilainya 85 .

Dengan melihat proses tahapan dua siklus dalam masing-masing pertemuan, mulai dari tahap pra-siklus, siklus pertama sampai akhir siklus II, kemampuan mahasiswa dalam bermain piano meningkat. Hal ini terlihat dalam penilaian hasil belajar yang masuk dalam kategori tinggi yang rata - rata nilainya berada di rentang 76 - 90 dan aktivitas mahasiswa selama proses perkuliahan berada dalam kategori baik. Dengan hasil wawancara, mahasiswa menginginkan mereka dapat memainkan karya piano duet empat tangan dengan tingkat kesulitan yang lebih tinggi dan pergantian peran antara primo dan secondo.

Hal lain yang sangat mendukung adalah bagaimana keputusan Dosen saat memilihkan patner bagi setiap pasangan. Berdasarkan hasil pengamatan masing-masing pasangan memiliki kekurangan dan kelebihan sehingga pada saat mereka harus bermain duet, menjadi moment yang saling melengkapi. Karya repertoar yang dimainkan mulai dari tingkat ritmis sederhana sampai yang rumit, selain itu sebagian karya lagu dengan variasi termasuk dalam karya populer sehingga lebih mudah untuk dimainkan berdua. Pada proses penjarian, mereka dapat secara otomatis memainkan lagunya karena mereka telah mendapatkan teknik tangganada dan trinada pada perkuliahan sebelumnya, sehingga teknik tersebut mendukung mahasiswa lancar dalam memainkan lagu. Hanya pada penggunaan pedal, hanya 2 pasangan yang partiturnya tertulis menggunakan 
pedal, sedangkan yang lain tidak karena penggunaan pedal memiliki tingkat kesulitan tersendiri.

Di sisi lain penggunaan keempat metode pembelajaran yaitu ceramah, tanya jawab, demonstrasi dan latihan / drill yang dilakukan oleh Dosen sekaligus peneliti berjalan baik dan lancar, sehingga tujuan pembelajaran yang telah dirancang secara efektif dapat mencapai hasil yang optimal.

\section{PENUTUP}

Berdasarkan hasil penelitian tindakan kelas dapat disimpulkan bahwa permainan duet piano empat tangan dapat meningkatkan kemampuan mahasiswa pada pembelajaran Praktek Instrumen Mayor 2 Piano di Jurusan Pendidikan Seni Musik. Peningkatan ini ditunjukkan dengan hasil perolehan nilai masing-masing komponen bagi pasangan duet berada pada kategori baik dan tinggi dengan rentang nilai 76 - 90 di setiap akhir siklus terutama diakhir siklus II. Pembelajaran menggunakan permainan duet piano empat tangan dapat dikategorikan berhasil. Oleh karena itu dapat dikatakan bahwa Dosen juga dapat meningkatkan strategi dan kualitas pembelajaran matakuliah piano terutama PIM 2. Disamping itu mahasiswa sendiri merasa dirinya mendapatkan perhatian dan kesempatan untuk mengembangkan kemampuan bermain pianonya, dan dengan adanya sikap saling bekerjasama mahasiswa mampu mempertanggungjawabkan tugas yang telah diberikan serta pada akhirnya mahasiswa dapat menguasai materi perkuliahan secara baik.

\section{DAFTAR PUSTAKA}

Arikunto, Suharsimi. 2014. Penelitian Tindakan Kelas. Jakarta: PT Bumi Aksara.

Banue, Pono. 2013. Metode Kelas Musik. Jakarta: PT Indeks.

Heru, Jelia Megawati. 2014. dalam Staccato Majalah Edukasi dan Informasi Musik. Duet Piano: Seni Bermain Piano dalam Ranah Ensemble. Sidoarjo: Media Profesional.

Kunandari. 2008. Langkah Mudah Penelitian Tindakan Kelas sebagai Pengembangan Profesi Guru. Jakarta: PT. Rajagrafindo Persada.

Last, Joan. 1989. Pianis Remaja. Jakarta: PT Gramedia.

Madya, Suwarsih. 1994. Seri Metodologi Penelitian. Panduan Penelitian Tindakan. Yogyakarta: Lembaga Penelitian IKIP Yogyakarta. 
Sanjaya, Wina. 2013. Strategi Pembelajaran. Jakarta: PT Raja Grafindo Persada.

Semiawan, C. 1984. Memupuk Bakat dan Kreativitas Siswa Sekolah Menengah. Jakarta: PT Gramedia.

Sugihartono. 2007. Psikologi Pendidikan. Yogyakarta: UNY Press.

Suryabrata, Sumadi, 2013. Metodologi Penelitian. Jakarta: PT Raja Grafindo Persada.

Wahyurini, Dini. 2009. Dalam Staccato Majalah Edukasi dan Informasi Musik. Sejarah Piano Duet. Sidoarjo: Media Profesional.

Winkel, W.S. 1986. Psikologi Pendidikan dan Evaluasi Belajar. Jakarta: PT Gramedia.

Wiriaatmadja, Rochiati. 2007. Metode Penelitian Tindakan Kelas untuk Menngkatkan Kinerja Guru dan Dosen. Bandung: PT Remaja Rosdakarya. 